\title{
Factors Affecting Women's Motivation to Perform a Cervical Cancer Screening Test
}

\author{
Henny Dwi Susanti ${ }^{*}$, Setyowati Setyowati ${ }^{2}$ and Yati Afiyanti ${ }^{3}$ \\ ${ }^{I}$ Departement of Nursing, Faculty of Health Science, University of Muhammadiyah Malang, Indonesia \\ Jalan Bendungan Sutami 188A Malang, Indonesia 65145 \\ ${ }^{2,3}$ Faculty of Nursing, University of Indonesia, Indonesia \\ Pondok Cina, Beji, Depok, Jawa Barat, 16424 \\ *Corresponding author: hanisusanti@yahoo.com
}

\begin{abstract}
Background: A disease that attracts world's attention and results the high mortality rate is cervical cancer. Lack of motivation is also caused by the ability of health workers to deliver and provide information early prevention of cervical cancer is not evenly distributed and properly socialized in addition to the social and economic factors, people with low socioeconomic, lazy to conduct investigation into the health service. Objective: The purpose of this research was to determine factors affecting women's motivation to perform a cervical cancer screening test. Method: This research was conducted using cross sectional. Collection of data on cross-sectional design using a questionnaire. Result: The most dominant factor affecting motivation was financial factor. Conclusion: It is recommended to increase women's motivation to perform a cervical cancer screening by developing a program and strategy suitable to women's capacities and needs.
\end{abstract}

Keywords: Motivation, women, cervical cancer screening

\section{INTRODUCTION}

National health system goals are to improve the health of women in an attempt to deal with problems that arise and to reduce mortality caused by several diseases. A disease that is currently the world's attention and resulted in a high mortality rate of cervical cancer. According to WHO (World Health Organization) in 2007 from 2329.08 million women aged> 15 years are at risk for cervical cancer. Every year 493243 women are diagnosed with cervical cancer and 273505 die from the disease. Mortality and the incidence of cervical cancer in women ranks second in the world after breast cancer, and often occurs in women aged between 15 and 44 years. It is estimated that each year 15050 Indonesian women diagnosed with cervical cancer and 7566 die from the disease, more than $70 \%$ of cases with cervical cancer in Indonesia was found when it reaches an advanced stage and came second in Indonesia after breast cancer between the ages of 15 to 44 years (WHO, 2007).

Medical record data from the General Hospital National Center Dr. Cipto Mangunkusumo shows that the number of cervical cancer in the year 2007 to 2011 which carry out checks on poly average amounted to 368 patients per year, while the hospitalization on average amounted to 259 per year, the data of patients in 2012 from January to October obtained Data that 327 patient examination Dipoli, meaning that the average patient examination as many as 27 patients per month and 275 people hospitalized, 203 of them aged between 46-65 years (Health report of RSCM , 2012).

According to WHO, in addition to lack of knowledge about cervical cancer, jobs and income as well as a factor of cervical cancer, cervical cancer is largely (80\%) occur in countries with low income, research in Turkey in 2007 obtained the results from 237 
respondents that $69.6 \%$ did not work, due to their low education and not to continue a higher level, so the impact on one's knowledge and motivation in screening (Guvenc et al, 2011). Lack of motivation is also caused by the ability of health workers to deliver and provide information early prevention of cervical cancer is not evenly distributed and properly socialized in addition to the social and economic factors, people with low socioeconomic, lazy to conduct investigation into the health service, because they assume the cost of treatment is expensive and access is not affordable, too far to health care and fear in people, so that they no motivation to be screened for cervical cancer that affects increasing cervical cancer patients with advanced stage (Monsonego, 2011).

Based on the results of research on the analysis of cervical cancer patient delay in shake-up at the General Hospital National Center Dr. Cipto Mangunkusumo, Jakarta, showed that the most dominant variable affecting the availability of services and pap smears. Research conducted in Turkey in 2007 titled scale model of trust health (health belief model of scale) for cervical cancer screening, showed that only $15.7 \%$ of the 237 respondents perform pap smears (Guvenc et al, 2011). Health belief model (HBM) is used to look at the behavior of health improvement. Model health trust is a cognitive model which means that cognitive processes are influenced by information from the environment. According to the health belief model of individual possibilities will take preventive action depending on the outcome of the two beliefs or one's perception and assessment of health, namely the perceived threat of pain and consideration of the advantages and disadvantages.

Threats that one feels, will lead a person thinking of disease or illness that are a threat to themselves, meaning that if a person feels threatened, it will automatically be prevention behaviors a person is also increasing, so it will change health behavior and appear motivated someone to carry out checks cervical cancer screening, with the appearance of one's motivation, it will decrease the incidence of cervical cancer by screening examination (Guvenc et al, 2011).To help prevent the high incidence of mortality and morbidity of patients with cervical cancer is detected at an advanced stage, and so that patients with cervical cancer motivated to perform screening for cervical cancer, it is necessary to intervene on all sides, so that people are motivated to do screening early. Based on the above and the high incidence in women suffering from cervical cancer, this study will investigate more about the factors that influence the motivation of women to cervical cancer screening examination.

\section{METHOD}

This study uses cross sectional (Burns \& Grove, 2009). Design is a design cross sectional analytic study that aims to determine the relationship between variables in which the independent variables and the dependent variable was identified in the unit of time, so that the researchers did not follow the respondent until a certain time (Dharma, 2011). The collection of data on cross-sectional design using a questionnaire. The sample used in this study was mostly women of childbearing age between the ages of 25-65 years who are in the health centers Cimanggis Depok City and met the study criteria (inclusion criteria) amounted to 116 respondents and was in the area health centers Cimanggis, Depok. The sampling using quota sampling. Regression technique used is the logistic regression analysis.

\section{RESULT AND DISCUSSION}

The results of this study were divided into three sections: the first section describes and interprets the characteristics of the respondent, the second section describes and interprets the relationship factors that influence the motivation of women to undertake screening for cervical cancer, in this section the findings are statistically explained by qualitative data 
obtained from interviews with 10 participants. The last section of the third part, explain and interpret the dominant factor affecting the motivation of women for cervical cancer screening examination. Characteristics of respondents analyzed by univariate, the table below will be presented a description of the characteristics of the respondent which include age, marital status, number of children, number of inspections, work, education, family income, financing, within the examination, the information media.

Table 1 Characteristics of Respondents

\begin{tabular}{|c|c|c|c|}
\hline No & Variable & $\mathbf{n}$ & $\%$ \\
\hline 1 & Age & & \\
\hline & $\begin{array}{l}25-45 \text { years } \\
46-65 \text { years }\end{array}$ & $\begin{array}{l}51 \\
65\end{array}$ & $\begin{array}{l}44 \\
66\end{array}$ \\
\hline 2 & $\begin{array}{l}\text { Marital Status } \\
\text { divorce } \\
\text { married } \\
\end{array}$ & $\begin{array}{l}8 \\
108 \\
\end{array}$ & $\begin{array}{l}6,9 \\
93,1 \\
\end{array}$ \\
\hline 3 & $\begin{array}{l}\text { Number of children } \\
0-3 \\
4-6\end{array}$ & $\begin{array}{l}75 \\
41\end{array}$ & $\begin{array}{l}64,7 \\
35,3\end{array}$ \\
\hline 4 & $\begin{array}{l}\text { Job } \\
\text { No } \\
\text { Yes }\end{array}$ & $\begin{array}{l}94 \\
22 \\
\end{array}$ & $\begin{array}{l}81 \\
19 \\
\end{array}$ \\
\hline 5 & $\begin{array}{l}\text { Education } \\
\text { Low } \\
\text { High }\end{array}$ & $\begin{array}{l}37 \\
79\end{array}$ & $\begin{array}{l}31,9 \\
68,1\end{array}$ \\
\hline 6 & $\begin{array}{l}\text { Financial } \\
\leq 2 \text { juta } \\
>2 \text { juta }\end{array}$ & $\begin{array}{l}86 \\
30\end{array}$ & $\begin{array}{l}74,1 \\
25,9\end{array}$ \\
\hline 7 & $\begin{array}{l}\text { Pay } \\
\text { No pay } \\
\text { pay }\end{array}$ & $\begin{array}{l}17 \\
99 \\
\end{array}$ & $\begin{array}{l}14,7 \\
85,3 \\
\end{array}$ \\
\hline 8 & $\begin{array}{l}\text { Far of check health } \\
>5 \mathrm{~km} \\
<5 \mathrm{~km}\end{array}$ & $\begin{array}{l}56 \\
60\end{array}$ & $\begin{array}{l}48,3 \\
51,7\end{array}$ \\
\hline 9 & $\begin{array}{l}\text { Information } \\
\text { Exposed } \\
\text { Not exposed }\end{array}$ & $\begin{array}{l}75 \\
41\end{array}$ & $\begin{array}{l}64,7 \\
35,3\end{array}$ \\
\hline
\end{tabular}

Table 1 shows that women who were respondents in this study according to age mostly between 46-65 years is 65 respondents (66\%). Judging from marital status, 108 respondents were married (93.1\%). Most have children between 0-3 children in $75(64.7 \%)$. Based on the job, most do not work amounted to 94 (81\%). The educational background of the respondents mostly higher education by 79 (68.1\%). Family incomes of less than 2 million were 86 respondents $(74.1 \%)$, and the cost of cervical cancer screening examination majority of $99(85.3 \%)$ of the respondents to pay. Distance inspects less than $5 \mathrm{~km}$ by 60 respondents $(51.7 \%)$ and the majority of respondents are exposed to media information for $75(64.7 \%)$ of respondents. 
Table 2 Distribution of frequencies according to knowledge, social support, feelings and motivations respondents

\begin{tabular}{llll}
\hline No & Variable & n & \% \\
\hline 1 & Knowledge & & \\
& Low & 20 & 17,2 \\
& High & 96 & 82,8 \\
\hline 2 & Social Support & & \\
& Low & 24 & 20,7 \\
& High & 92 & 79,3 \\
\hline 3 & Feeling & & \\
& Negative & 112 & 96,6 \\
& Positive & 4 & 3,4 \\
\hline 4 & Motivation & & \\
& Low & 23 & 19,8 \\
& High & 93 & 80,2 \\
\hline
\end{tabular}

Table 2 shows that knowledge about cervical cancer screening examinations mostly high or good by 96 (82.8\%), social support among respondents about cervical cancer screening examinations mostly higher as many as 92 respondents (79.3\%). Respondent's feelings about cervical cancer largely negative $112(96.6 \%)$ and the motivation of the respondent about cervical cancer screening examinations most of $93(80.2 \%)$ high.

Table 3 shows the results of analysis of the relationship between age and motivation showed that there were 50 women $(76.9 \%)$ were aged 46-65 years tend to have high motivation, whereas among women aged 25-45 years, there are 43 women (84.3\%) have a high motivation to do the screening. Statistical test results obtained by value $p=0.324, \alpha=$ 0.05 , we can conclude there is no significant relationship between age and motivation. The results of the analysis of correlation values (OR) in the amount of 0.620 to $95 \%$ CI 0.240 to 1.603, meaning that women aged 46-65 years have the opportunity 0.620 times highly motivated to perform cervical cancer screening than women aged 25-45 years, with interval / 95\% confidence level between 0.240 to 1.603 .

Selecting the variables to be included in the multivariate analysis. Variables that were included in the multivariate analysis are variables in the bivariate analysis has a value of $p<0.25$. This means that at this stage variable that has a value of $p<0.25$ included in the modeling, while variable which has a value of $p>0.25$ were excluded from modeling. The next of these five variables multivariate analyses using backward. In the backward method, all selected variables entered into the multivariate, and gradually influential variables will be excluded from the analysis. The process will be stopped until no more variables that can be excluded from analysis. Table 4 shows the results of logistic regression analyzes first modeling using backward method, there are 4 steps to get on the end result. In the above modeling, education variable has a value of $\operatorname{Exp}(\mathrm{B})$ the smallest, so that the educational variables were excluded from the modeling.

Table 5 shows that the variable income, financial and social support incorporated into the modeling. In modeling the above, the income variable has a value of $\operatorname{Exp}(B)=2.718$, financing $\operatorname{Exp}(B)=3,740$ social support $\operatorname{Exp}(B)=2,500$. In the second model, the variable has a value jobs $\operatorname{Exp}(\mathrm{B})$ the smallest is 1.710 . so the variables excluded from the modeling work next / third. In the third step, variable income, financial and social support incorporated into the modeling. Variable income $\operatorname{Exp}(\mathrm{B})=3.036$, financing $\operatorname{Exp}(\mathrm{B})=3.809$, social support $\operatorname{Exp}(\mathrm{B})=2.366)$. Exp $(\mathrm{B})$ on social support is smaller than the variable income and financing, so that the social support variables were excluded from further modeling / four (Table 6). 
Table 3 The relationship between the age, marital status, number of children, spacing checks, employment, education, income, finance, media information, knowledge, social support, feelings to motivate women

\begin{tabular}{|c|c|c|c|c|c|c|c|c|}
\hline \multirow[t]{2}{*}{ Variable } & Motivation & vation & \multicolumn{2}{|c|}{ High } & Total & \multirow[b]{2}{*}{$\%$} & \multirow{2}{*}{ OR $(95 \% \mathrm{CI})$} & \multirow{2}{*}{$p$-value } \\
\hline & $\mathrm{n}$ & $\%$ & $\mathrm{n}$ & $\%$ & $\mathrm{n}$ & & & \\
\hline \multicolumn{9}{|l|}{ Age } \\
\hline - 25-45 Years & 8 & 15,7 & 43 & 84,3 & 51 & 100 & 0,620 & 0,324 \\
\hline - 46-65 Years & 15 & 23,1 & 50 & 76,9 & 65 & 100 & $0,240-1,603$ & \\
\hline \multicolumn{9}{|l|}{ Marital Status } \\
\hline - Divorced & 1 & 12,5 & 7 & 87,5 & 8 & 100 & 0,558 & 0,595 \\
\hline - $\quad$ Married & 22 & 20,4 & 86 & 79,6 & 108 & 100 & $0,065-4,780$ & \\
\hline \multicolumn{9}{|l|}{ Children } \\
\hline - $0-3$ & 13 & 17,3 & 62 & 82,7 & 75 & 100 & 0,650 & 0,364 \\
\hline - $4-6$ & 10 & 24,4 & 31 & 75,6 & 41 & 100 & $0,256-1,648$ & \\
\hline \multicolumn{9}{|l|}{ Distance Inspection } \\
\hline - Far & 13 & 23,2 & 43 & 76,8 & 56 & 100 & 1,512 & 0,851 \\
\hline - Close & 10 & 16,7 & 50 & 83,3 & 60 & 100 & $0,603-3,792$ & \\
\hline \multicolumn{9}{|l|}{ Work } \\
\hline - Jobless & 21 & 22,3 & 73 & 77,7 & 94 & 100 & 2,877 & 0,177 \\
\hline - Work & 2 & 9,1 & 20 & 90,9 & 22 & 100 & $0,621-13,318$ & \\
\hline \multicolumn{9}{|l|}{ Education } \\
\hline - Low & 10 & 27,0 & 27 & 73,0 & 37 & 100 & 1,880 & 0,187 \\
\hline - High & 13 & 16,5 & 66 & 83,5 & 79 & 100 & $0,736-4,805$ & \\
\hline \multicolumn{9}{|l|}{ Income } \\
\hline - $\leq 2$ Million & 20 & 23,3 & 66 & 76,7 & 86 & 100 & 2,727 & 0,128 \\
\hline - $>2$ Million & 3 & 10 & 27 & 90 & 30 & 100 & $0,748-9,942$ & \\
\hline \multicolumn{9}{|l|}{ Financing } \\
\hline - Not Paying & 7 & 41,2 & 10 & 58,8 & 17 & 100 & 3,631 & $0,022^{*}$ \\
\hline - Pay & 16 & 16,2 & 83 & 83,8 & 99 & 100 & $1,204-10,955$ & \\
\hline \multicolumn{9}{|l|}{ Media Information } \\
\hline - Exposed & 14 & 18,7 & 61 & 81,3 & 75 & 100 & 0,816 & 0,672 \\
\hline - Unexposed & 9 & 22,0 & 32 & 78,0 & 41 & 100 & $0,319-2,090$ & \\
\hline \multicolumn{9}{|l|}{ Knowledge } \\
\hline - Low & 4 & 20,0 & 16 & 80,0 & 20 & 100 & 1,013 & 0,983 \\
\hline - High & 19 & 19,8 & 77 & 80,2 & 96 & 100 & $0,304-3,381$ & \\
\hline \multicolumn{9}{|l|}{ Social Support } \\
\hline - Low & 8 & 33,3 & 16 & 66,7 & 24 & 100 & 2,567 & 0,068 \\
\hline - High & 15 & 16,3 & 77 & 83,7 & 92 & 100 & $0,932-7,069$ & \\
\hline \multicolumn{9}{|l|}{ Feeling } \\
\hline - Negative & 22 & 19,6 & 90 & 80,4 & 112 & 100 & 0,733 & 0,792 \\
\hline - Positive & 1 & 25,0 & 3 & 75,0 & 4 & 100 & $0,073-7,393$ & \\
\hline
\end{tabular}

Table 4 Relationship employment, education, income, finance, social support on the motivation of women to carry out checks for cervical cancer screening

\begin{tabular}{lll}
\hline Variabel & p value & Exp $(\mathbf{B})$ \\
\hline Work & 0.484 & 1.794 \\
Income & 0.196 & 2.534 \\
Financing & 0.031 & 3.602 \\
Social Support & 0.096 & 2.469 \\
Education & 0.403 & 1.550 \\
\hline
\end{tabular}


Table 5 Relationship variable income, financing, social support on the motivation of women to carry out checks for cervical cancer screening

\begin{tabular}{lll}
\hline Variable & p value & Exp (B) \\
\hline Income & 0.159 & 2.718 \\
Financing & 0.025 & 3.740 \\
Social support & 0.090 & 2.500 \\
Work & 0.484 & 1.710 \\
\hline Constanta & 0,227 & 0,413 \\
\hline
\end{tabular}

Table 6 Relationship variable income, financing, social support on the motivation of women to carry out checks for cervical cancer screening

\begin{tabular}{lll}
\hline Variable & p value & Exp (B) \\
\hline Income & 0.109 & 3.036 \\
Financing & 0.023 & 3.809 \\
Social Support & 0.109 & 2.366 \\
\hline Constanta & 0,407 & 0,580 \\
\hline
\end{tabular}

Table 7 Relationship variable income, financing on the motivation of women for cervical cancer screening examination

\begin{tabular}{lll}
\hline Variable & p value & Exp (B) \\
\hline Income & 0.103 & 3.029 \\
Financing & 0.018 & 3.965 \\
\hline Constanta & 0,908 & 1,063 \\
\hline
\end{tabular}

Table 7 show the variable income and financing included in the modeling. $\mathrm{P}$ value in the variable income of 0.103 with $\operatorname{Exp}(\mathrm{B})=3.029$. $\mathrm{P}$ value in the variable financing amounted to 0,018 with niali $\operatorname{Exp}(B)=3.965$, so that aspect of financing is the dominant variable affecting because it has the value of $\operatorname{Exp}(\mathrm{B})$ the large and p value $<0.05$.

Statistical test results showed that the financing at variable significant correlation between financing with the motivation of women for cervical cancer screening examination. This is consistent with the findings that most of the respondents were able to pay and is motivated to do cervical cancer screening examinations. Correspondingly, according to the Health Belief Model theory explained that someone will use health services, if he is able to use it, use the health service depends on one's ability to pay. The study reported that, financing is an important supporting factor and greatly affect the motivation of women for cervical cancer screening examination.

The results do not correspond with those implemented in developed countries, because most of the developed countries provide health insurance to its citizens (Goldie, 2005; Chow, 2011). Research conducted by Dasbach, et al (2008) in English explaining that to anticipate and increase the motivation of women for cervical cancer screening examination, the British government makes cervical cancer screening program at no cost. So also conducted in Turkey that the majority (85\%) receive health insurance from the government of Turkey (Esin, 2011). This is very different from the situation in developing countries like Indonesia, where women spend most of their own to carry out checks for cervical cancer screening for the sake of his health. Statistical test results on a variable income obtained that there is no relationship between income and motivation of women for cervical cancer screening examination. In fact the majority of respondents with incomes of less than 2 million highly motivated to perform cervical cancer screening examinations. This is supported by studies conducted on women in Tanzania, that women with low income will attempt to do cervical cancer screening for the sake of his health. (Lyimo \& Beran, 2012). This is supported by interviews of the participants, that the vast majority of women are motivated to perform cervical cancer screening 
examination for health reasons, although penghasilannnya less than 2 million. This is because, women seek to be doing and trying to seek treatment at any cost, in order to achieve health.

Statistical test results on social support variables showed that no significant relationship between social support and motivation. In fact, most of the people get the support, has a high motivation to perform cervical cancer screening examinations. This is consistent with the results of interviews, most participants supported both by their husbands, families and health care workers to be motivated to take the examination for cervical cancer screening. Research conducted in Zambia on 60 women about their experiences as motivation and conduct screening to prevent cervical cancer showed that support from family greatly affects women to be motivated to take the examination for cervical cancer screening (White, et al, 2011). Correspondingly, research conducted by Akhtar et al (2010), of the multidimensional scale of perceived social support explained that social support is one of the interventions to improve and change a person's behavior (Ramaswamy et al, 2009; Akhtar et al, 2010). According to the theory of reinforcing factor, the factor that leads to a person's behavior is the attitude and behavior of health workers is very important in this factor, which means that the support of health workers is to provide education or health promotion by doing counseling about cervical cancer. Based on Health Belief Model theory, explained that the psycho-social variables in this case one variable is social support, are variables / factors that predispose a person to act, which means that women will be motivated to perform screening for cervical cancer when you get social support. The result of the above, according to the results of research, that most respondents received support from her husband, family and health workers. The study reported that, social support, either from health officials, her husband and family is very important in motivating a person to adopt healthy behaviors. This may imply that in order to achieve a healthy person's behavior, then it should start from the smallest order of the husband, the family of the officer kesehata further support, so that the presence of a conducive environment, will appear motivated person to carry out inspection of cervical cancer screening.

Statistical test results of variable work shows that there is no relationship between the work with the motivation of women for cervical cancer screening examination. In fact most of the respondents who do not work have a high motivation to perform cervical cancer screening examinations. The study reported that women who do not have jobs do not necessarily have low motivation to perform cervical cancer screening examinations. These results are consistent with research conducted by Logan (2011), explaining that women who do not possess a job, not necessarily their perceptions and motivations of the lower cervical cancer screening (Ansink et al, 2004; Logan, 2011). The results of statistical tests for the educational variables showed that there was no relationship between education and motivation of women for cervical cancer screening examination. In fact most of the respondents who have high levels of education have a high motivation to perform cervical cancer screening examinations. The study reported that, the higher one's education, the higher the person's motivation to adopt healthy behaviors to perform cervical cancer screening examinations. These results are according to the results of research conducted by Logan (2011) on women in the United Kingdom, explained that the factors that encourage women to undertake screening for cervical cancer is the level of one's education, the higher the level of education a person, the more motivated of the women of the screening examination cervical cancer (Logan, 2011).

Statistical test results in variable feeling threatened cervical cancer will be found that there is no significant relationship between feelings and motivation of women for cervical cancer screening examination. In fact the majority of respondents who feel threatened will have feelings of cervical cancer has a high motivation to perform cervical cancer screening examinations. in line with the qualitative research conducted by Logan (2011), said that the participants will express his fear of cervical cancer. A similar study conducted by Wong 
(2008), that women's fear of cervical cancer. These results are consistent with the theory Health Belief Model explained that a person's feelings that he felt threatened by the disease, ie, the greater the disease threatened his health, then one's view will be more severe, so it would appear someone's motivation in seeking treatment in an attempt to prevent or cure diseases (Benson \& Dundis, 2003). Individual motivation in acting to treat or prevent the disease, people should feel that they are vulnerable (susceptible) to the disease (cervical cancer) is. In other words, a countermeasure against a disease occurs when a person has the feeling that women are vulnerable to disease (cervical cancer) ( $\mathrm{Gu}$ et al, 2010). This would suggest that the more a person feels vulnerable and threatened with cervical cancer, the more motivated and act to behave. In accordance with the results obtained from the respondents in Puskesmas Cimanggis majority of respondents expressed fear of cervical cancer.

Statistical test results in the variables obtained knowledge that there is no significant relationship between knowledge and motivation of women. In fact most of the respondents who have high knowledge have high motivation to perform cervical cancer screening examinations. It is supported by the results of research with interviews, most participants found out about the definition of cervical cancer, signs and symptoms of cervical cancer, and the risk factors and the prevention of cervical cancer (Al-Naggar\& Isa, 2010; Chow et al, 2010). Research conducted by Gu Can, et al (2010) about the influence of knowledge of women about cervical cancer on the behavior of cervical cancer screening for women in China explained that women who have high knowledge about cervical cancer affect the behavior of a person to perform screening for cervical cancer. Correspondingly, research conducted by Dim (2012), states that knowledge will affect one's motivation to maintain their reproductive health (Tran et al, 2010; Aswathy et al, 2012; Dim, C. C. (2012)

Qualitative research that support is the research conducted by Forss (2001) on women in Sweden, explains that women are motivated to perform screening for cervical cancer early is because most of these women understand the definitions and risk factors for cervical cancer (Forss et al, 2001). It is powered from the results of interviews with 10 participants that most participants could explain the definitions, signs and symptoms and risk factors of cervical cancer screening. The study reported that high knowledge about cervical cancer and its prevention can affect a person's behavior to seek health care, which will have an impact on people's motivation to perform cervical cancer screening examinations. The above results are not supported by research conducted by Guvenc et al (2011), of the health belief model of scale for cervical cancer and pap smear test: psychometric testing. The study explains that in order to determine the behavior of women to do a pap smear and a desire to do a pap smear then performed the first survey to 6 groups among which: the first group precontemplation, never do a pap smear test and never think to do a pap smear in 6 months forward. The second group Contemplation, never do a pap smear test, but thought to do a pap smear test 6 months. Preparation, never did the pap smear test, but think will do a pap smear test next month. Action, ever having a Pap smear and want to do a pap smear again. Maintenance, Doing pap smear regularly and then to continue to conduct the review. Relapse, ever do a pap smear, but there is no desire to do a pap smear test.

Characteristics of respondents are discussed in this study were age, marital status, number of children, employment, education. Selection of variables that asked the respondents adapted to past studies that included respondents characteristic data to determine the factors that influence the motivation of women for cervical cancer screening examination such as age, education level, occupation, number of children, and marital status (Gu et al, 2010; Vesco et al, 2011). Statistical test results at age variable indicates that there is no relationship between age and motivation of women for cervical cancer screening examination. In fact the majority of respondents aged 46-65 years (age at menopause) have a high motivation to perform cervical cancer screening examinations. These results are supported by the results of 
a qualitative study found that participants who had to perform cervical cancer screening examination is at the age of menopause. High motivation to carry out checks on the age of menopause due to the highly vulnerable and at risk of cervical cancer. This is consistent with the results of a survey conducted by researchers at the National Center General Hospital Dr. Cipto Mangunkusumo in January to the month of October 2012 showed that the majority of women who undergo cervical cancer at the age of menopause is between 46 to 65 years that is equal to 203 women out of 327 patients with cervical cancer (Health report of RSCM , 2012). The high incidence of cervical cancer in that age range will motivate women for cervical cancer screening examination. The number of respondents who conduct screening examinations also supported the recommendations of the USPSTF (US Preventive Services Task Force) that women who undergo screening examinations performed until the age of 65 years.

The results of statistical tests for variables marital status, it can be concluded that there is no significant relationship between marital status and motivation. In fact there is a relationship between marital status with high motivation, it is supported on the results of interviews with participants that both women were already married and unmarried who had sexual intercourse, it is recommended cervical cancer screening examination. In accordance with the recommendation of the ACS (American Cancer Society) recommends for pap smear tests carried out three years after a person's sexual intercourse, meaning that women who have had sexual intercourse, both married and unmarried highly recommended to perform screening for cervical cancer (Andrijono, 2012).

Accordingly, the results of research conducted by the Australian National Cervical Screening Program recommends that women who are already sexually active are encouraged to perform cervical cancer screening every one to two years (Australian Institute of Health and Welfare, 2009; Olesen et al, 2012). It is supported by the results of the interview respondents, stated that women either already married or not married and had sexual intercourse have the motivation to perform cervical cancer screening examinations. The study reported that women who have intercourse have the risk factors of cervical cancer, so the motivation of women for cervical cancer screening examination is highly recommended.

Statistical test results on a variable number of children showed no relationship between the number of children with the motivation of women for cervical cancer screening examination. In fact most of the respondents have a high motivation to perform cervical cancer screening examinations. The study reported that having too many children may be at risk of cervical cancer. When a woman giving birth naturally, the fetus will pass through the cervix and cause trauma to the cervix, which can trigger active cancer cells. According to the Ministry of Health (2008), explaining that women who gave birth more than three times a risk factor for complications, such as cervical cancer. Seeing these conditions, it will motivate women for cervical cancer screening examination. The more often fetus passes through the cervix, the more trauma occurred, so the higher the risk of cervical cancer. The motivation of women for cervical cancer screening examination will also increase. The data is also supported by the expression on the interview of the respondents that women at risk of cervical cancer occurs is a woman who has many children and often give birth, so most women have a high motivation to perform cervical cancer screening examinations.

\section{CONCLUSION}

This research can be concluded that the factors that influence the motivation of women for cervical cancer screening examination is employment, education, income, financial and social support. The most dominant factor affecting the financing is variable. Based on the 
results of interviews with women for cervical cancer screening examination said that with the discovery of early, treatment is cheaper.

\section{REFERENCES}

Akhtar, A., Rahman, A., Husain, M., Chaudhry, I. B., et al. (2010). Multidimensional scale of perceived social support: psychometric properties in a South Asian population. The Journal of Obstetrics and Gynaecology Research, 36(4), 845-851.

Al-Naggar, R. A., \& Isa, Z. M. (2010). Perception and opinion of medical students about Pap smear test: a qualitative study. Asian Pacific Journal of Cancer Prevention: APJCP, 11(2), 435-440. American Cancer Society, 2006, Cancer Facts and Figures 2006, American Cancer Society Inc. Atlanta

Andrijono (2012). Kanker Serviks, FIK-UI : Divisi Onkologi Departemen Obgyn

Ansink AC, Tolhurst R, Haque R, Saha S. (2008). Cervical cancer in Bangladesh: community perceptions of cervical cancer and cervical cancer screening. Transactions of the Royal Society of Tropical Medicine and Hygiene, 102:499-505

Aswathy, S., Quereshi, M. A., Kurian, B., \& Leelamoni, K. (2012). Cervical cancer screening: Current knowledge \& practice among women in a rural population of Kerala, India. The Indian Journal Of Medical Research, 136(2), 205-210.

Australian Institute of Health and Welfare (2009). Cervical screening in Australia 2006-2007. Cancer Series no 47 Cat no CAN 43 Canberra: AIHW.

Burns, N \& Grove, Susan K .(2009). The Practice of Nursing Research, United States of America : Elsevier

Chow, I. H. I., Tang, C. H., You, S. L., Liao, C. H., et al. (2010). Cost-effectiveness analysis of human papillomavirus DNA testing and Pap smear for cervical cancer screening in a publicly financed health-care system. British Journal Of Cancer, 103(12), 1773-1782.

Dasbach, E. J., Insinga, R. P., \& Elbasha, E. H. (2008). The epidemiological and economic impact of a quadrivalent human papillomavirus vaccine $(6 / 11 / 16 / 18)$ in the UK. BJOG: An International Journal Of Obstetrics And Gynaecology, 115(8), 947-956.

Dharma, K.K. (2011). Metodologi Penelitian Keperawatan. Jakarta : Trans Info Media.

Dim, C. C. (2012). Towards improving cervical cancer screening in Nigeria: A review of the basics of cervical neoplasm and cytology. Nigerian Journal Of Clinical Practice, 15(3), 247-252.

Esin, M. N., Bulduk, S., \& Ardic, A. (2011). Beliefs about cervical cancer screening among Turkish married women. Journal of Cancer Education: The Official Journal of The American Association for Cancer Education, 26(3), 510-515.

Forss, A., Tishelman, C., Widmark, C., Lundgren, E., Sachs, L., \& Törnberg, S. (2001). 'I got a letter...' a qualitative study of women's reasoning about attendance in a cervical cancer screening programme in urban Sweden. Psycho-Oncology, 10(1), 76-87.

Goldie, S. J., Gaffikin, L., Goldhaber-Fiebert, J. D., Gordillo-Tobar, A., et al. (2005). Costeffectiveness of cervical-cancer screening in five developing countries. The New England Journal of Medicine, 353(20), 2158-2168.

Guvenc, G., Akyuz, A., \& Açikel, C. H. (2011). Health Belief Model Scale for Cervical Cancer and Pap Smear Test: psychometric testing. Journal of Advanced Nursing, 67(2), 428-437. doi: 10.1111/j.1365-2648.2010.05450.x

Gu, C., Chan, C. W. H., \& Twinn, S. (2010). How sexual history and knowledge of cervical cancer and screening influence Chinese women's screening behavior in mainland China. Cancer Nursing, 33(6), 445-453.

Health report of RSCM , (2012), Data Health report of RSCM. Jakarta 
Logan, L., \& McIlfatrick, S. (2011). Exploring women's knowledge, experiences and perceptions of cervical cancer screening in an area of social deprivation. European Journal Of Cancer Care, 20(6), 720-727. doi: 10.1111/j.1365-2354.2011.01254.x

Lyimo, F. S., \& Beran, T. N. (2012). Demographic, knowledge, attitudinal, and accessibility factors associated with uptake of cervical cancer screening among women in a rural district of Tanzania: Three public policy implications. BMC Public Health, 12, 22-22

Ministry of Health (2008). Kesehatan Ibu. diunduh pada tanggal 20 desember 2012 dari http://www.depkes.go.id

Monsonego, J., Cortes, J., da Silva, D. P., Jorge, et al. (2011). Psychological impact, support and information needs for women with an abnormal Pap smear: comparative results of a questionnaire in three European countries. BMC Women's Health, 11, 18-18.

Olesen, S. C., Butterworth, P., Jacomb, P., \& Tait, R. J. (2012). Personal factors influence use of cervical cancer screening services: epidemiological survey and linked administrative data address the limitations of previous research. BMC Health Services Research, 12, 34-34.

Pavia, C., Navarra, A., Pisani, G., Piselli, P., et al. (2006). [Knowledge and use of Pap-smear among HIV-positive women]. Minerva Ginecologica, 58(3), 233-238.

Ramaswamy, V., Aroian, K. J., \& Templin, T. (2009). Adaptation and psychometric evaluation of the multidimensional scale of perceived social support for Arab American adolescents. American Journal Of Community Psychology, 43(1-2), 49-56.

Tran, J. H., Mouttapa, M., Ichinose, T. Y., Pang, et al. (2010). Sources of information that promote breast and cervical cancer knowledge and screening among native Hawaiians in Southern California. Journal Of Cancer Education: The Official Journal Of The American Association For Cancer Education, 25(4), 588-594.

Vesco, K. K., Whitlock, E. P., Eder, M., Burda, et al. (2011). Risk factors and other epidemiologic considerations for cervical cancer screening: a narrative review for the U.S. Preventive Services Task Force. Annals Of Internal Medicine, 155(10), 698.

Wong, L. P., Wong, Y. L., Low, W. Y., Khoo, E. M., \& Shuib, R. (2008). Cervical cancer screening attitudes and beliefs of Malaysian women who have never had a pap smear: a qualitative study. International Journal Of Behavioral Medicine, 15(4), 289-292. doi: 10.1080/10705500802365490

White, H. L., Mulambia, C., Sinkala, M., Mwanahamuntu, et al. (2012). Motivations and experiences of women who accessed "see and treat" cervical cancer prevention services in Zambia. Journal of Psychosomatic Obstetrics and Gynaecology, 33(2), 91-98. doi: 10.3109/0167482x.2012.656161

WHO, (2007), HPV and Cervical Cancer in The World 2007 Report, diunduh pada tanggal 06 September 2012 dari http://www.who.int/hpvcentre. 